\title{
New Pioneers of Cairns: 1950 - 2000
}

\section{Carol Libke}

\author{
Independent Researcher
}

\begin{abstract}
This paper will include the voices of some of the people that will be included in a book I am currently writing entitled New Pioneers of Cairns: $1950-2000$. This 50-year period encompasses the rebuilding phase of Cairns following the Second World War. Today I will highlight the stories of the people I refer to as 'New Pioneers' and acknowledge their contribution to Cairns. The primary reason for writing the book is to recognise those who have contributed to the growth of the region, to say 'thank you' while these people are still alive and to leave a lasting historical record for the generations that follow.

This history begins in 1950, at a time when the population of Cairns numbered just 16, 800 permanent residents in a, predominantly, bicycle town. Large families with tight budgets meant little thought of pursuing higher education. Generally, older children left school at scholarship (the equivalent of Grade 8) to help make ends meet. At that time, jobs in Cairns were plentiful and usually filled by word of mouth with parents usually 'having a word', on behalf of their children, in the ear of the owner of a particular firm. In turn, business owners often knew the family and their dedication, or otherwise, to a working environment.
\end{abstract}

Ron Davis left school as a thirteen-year-old after attending Cairns High School. He is a good example of how a local lad could aspire to becoming Mayor.

Davis recalls (Davis, Interview, 12 Feb. 2015):

"My first job was in the Kapok pillow section of A J Drapers, between Lake and Abbott Streets. In the 1950s, Cairns High School provided a 'night school' to enable people to move into better paying careers. Straight from work I attended night school until 9pm. I stayed on in the firm and managed to work my way up to Secretary/Accountant."

Ron Davis went on to become Mayor of Cairns (1978-1988).

During the 1950s and 1960s the timber and sugar industries engaged a large majority of locals. Some locals also ran family businesses, with the expectation that children would follow parents into the business. Examples of businesses that have been handed down from father to son are: Ireland's cars, Piccone's food stores, Harris Brothers drapers and mercers, as well as a number of butcher shops. The expectation was that the next generation would grow and develop the business.

However Greek immigrant George Comino, who had arrived in Australia as a penniless 16-year-old, had other ideas. Comino's Cafe, where Orchid Plaza stands 
today, was noted for its starched tablecloths, gleaming cutlery and polite staff. It soon became the social hub of Cairns. By the early 1950s, George Comino had become a successful businessman with a growing family and a Cafe that was regarded as one of Australia's most modern establishments of its kind. Therefore, it came as a complete shock to locals when Comino decided to auction off all the furniture and fittings and close the doors on a highly successful business.

Son Peter Cominos (dropped apostrophe) explains: (Cominos, Interview, 8 Aug. 2015)

"Dad was starting to feel his age. He put it around town that he was selling because he couldn't bear the thought of someone running the Cafe into the ground. But we knew the real reason. Dad didn't want to see any of us running it. His sights were set a lot higher for us. In those days, migrants worked very hard and sacrificed their lives to see their children to succeed.

Of course, we were expected to help in the Cafe. We learned how to run a business. The expectation was that we would study hard and make our parents proud."

Peter Cominos became a well-regarded pharmacist who ran three Chemist shops in Cairns.

In 1986, following the death of their parents, the Cominos siblings (all engaged in professional careers) offered the family home to the Cairns City Council for use by community groups. In 1988, a combined effort the Council (under Mayor Goodwin), the Cominos Family (who donated \$100,000) and Volunteers oversaw the relocation and refurbishment of Cominos House to Greenslopes Street, the cultural hub of Cairns.

The house, built in 1877, remains as a typical example of a highset Queenslander and is regarded as one of the most well-known and best-loved buildings in Cairns. Following restoration Cominos House was eventually occupied by a group of Community Arts and Environment Organisations.

Another family to have left a legacy for Cairns is the Norman Family whose patriarch rose from humble beginnings to be awarded a knighthood.

Bob Norman, son of the late Sir Robert Norman, recalls an amusing day when helping his father in his dry-cleaning shop on Grafton Street: a former red-light district called Sachs Street until 1939. (Norman, Interview, 26 Mar. 2015)

"I was quite young, but I remember a young Constable from the Police Station on the Esplanade coming in with a large pair of woollen trousers and a special request from the Sergeant to remove a huge ink stain that covered the front of the trousers.

In those days, the usual turnaround for dry-cleaning was one week. It was big business. But, seeing as the Constable was instructed to wait, within the hour 
the ink stain was removed and the trousers pressed. Heading for the door the Constable remarked that the Sergeant would be very pleased since he had been waiting at the Station in his underpants."

After establishing a very successful dry-cleaning business Bob Norman Snr, who had served as a pilot in Canada during World War II, set up Bush Pilots Airways, operating out of Cairns.

In 1956, as cyclone Agnes bore down on the Far North Queensland coast, Norman ignored warnings that there would be no search and rescue if he attempted to fly his tiny Tiger Moth to the Peninsula district to make food drops and warn station owners of the impending cyclone. In 1958, Norman's rescue efforts earned him an OBE.

By 1989, Bob Norman had become an extremely community-minded businessman, having crucial involvement in the establishment of the James Cook University Cairns Campus and the Cairns Regional Art Gallery. He was honoured with the fourth, and final, knighthood awarded within the Cairns region. Thereafter, the Australian government ceased recommendations for Imperial awards and established 55 different types of awards to honour worthy recipients from a variety of ethnicities.

Since the establishment of Cairns in 1876, tenacity and resourcefulness had been the hallmark of the Chinese community. During the 1950s and 1960s Cairns Chinatown had been the largest and longest running of its type outside Brisbane. Market gardens stretched like a green sea behind fruit and vegetable, and herbalist stores dotted along Grafton (formerly Sachs) Street. For more than 80 years, the Lit Sun Goong temple provided a place of worship for local Chinese folk until 1964 when the dilapidated building was razed. Today the Cairns and District Chinese Association Inc (CACAI) Heritage group oversee the preservation of artefacts such as the altar, the deity and the temple bell, which have national significance.

On the far side of the inlet softly spoken Chinese octogenarian, George Wah Day, recounts a proud family history of farming the eastern side of Trinity Inlet for more than 100 years (Wah Day, Interview, 5 Jun. 2015).

"Some people joke that we've been there so long that Captain Cook must have bought fruit and veg from us before naming Trinity Bay.

I recall my father regularly rowing me, and a load of fruit and vegetables, across the inlet. I went to Parramatta State School for half a day, or sometimes a whole day, if Dad had a lot of business to do around town. The teachers understood when I said it was time for me to go, but I still managed to learn how to read and write, and do my sums."

Over time, the six Wah Day brothers bought out neighbouring properties, thus upping the quota on their cane farms while expanding the citrus and lychee plantation. The family looked into marketing opportunities and established the first prawn farm in the area, supplying boxed frozen prawns to restaurants in Sydney and Melbourne. 
In 1954, the Commonwealth Department of Immigration, under the leadership of Arthur Calwell, encouraged non-British mainly from countries such as Italy, the Netherlands, Germany and the former Yugoslavia to call Australia home.

Many assisted passage Italian canecutters heeded the call and put all their faith in a two-year contract that would see them boarding migrant ships to the other side of the world. Hurtful names such as Wog and Dago greeted them. Soon Italians with the name Maria began to answer to Mary, Nunzia to Nancy, Salvatore to Sam, and so on.

Franco (Frank) Bianco recalls arriving in Cairns, as a 10-year-old boy in 1955, aboard the Flamina. (Bianco, Interview, 4 Apr. 2015)

"After the ship docked we were taken to the Hartley Street Immigration Centre. Dad rode the rail-motor out to Edmonton to cut cane and stayed in barracks there during the week. He came home on weekends and took me fishing.

During the week, the bus arrived at the camp to take the Catholic children to St Joseph's Convent. The nuns were strict but kind. Most kids arrived with no English but we picked up the language pretty quick. We soon learned that Dago and Wog were disparaging terms, meant to hurt us, because we weren't considered White. Six months later, Dad got a job on the new Tinaroo Dam project and our family moved up to the Atherton Tableland."

By 1965, under Prime Minister Harold Holt, both major political parties had removed the words 'White Australia' from all political platforms. Thus, regardless of race, non-Europeans were encouraged to become Australian citizens. Nevertheless, the winds of change had started to blow.

By the mid-60s, mechanical harvesting had relegated 'gun' cane cutters to obscurity as this new form of harvesting provided a faster, cheaper and easier way of cutting and loading sugar cane. Further, the drop in the World Sugar price effectively shut down the once robust towns of Edmonton and Gordonvale, while Babinda's fortunes went into steady decline.

Meanwhile in Cairns the Hayles family, that had been ferrying visitors to Green Island since 1924, continued to fly the tourism flag. In 1954, the island became increasingly popular when Vince Vlasoff and Lloyd Grigg opened the world's first underwater observatory at the end of the jetty.

During the early 1960s famed Australian filmmaker Noel Monkman and his wife Kitty, who lived on the Green Island, opened the world's first island movie theatre. Producing engaging colour films, the filmmakers showed the enchanting beauty of the reef juxtaposed with tales of survival in a deep underwater world.

Back in Cairns a community of Aborigines, Torres Strait Islanders and people of mixed heritage lived on the banks of Alligator Creek (where bulk fuel tanks are now located on the corner of Bunda and Kenny Streets). The area, established in the 
early 1900s, could best be described as the first example of multi-culturism at work in Cairns. The name came about due to the mix of Chinese, Japanese, Malays, Jamaicans, South Sea Islanders, Filipinos, Aborigines and Torres Strait Islanders who fished, worked in the trochus shell industry or loaded sugar on to container ships.

The Pitt, Sailor and Walters' families are among the most prominent of the Torres Strait Islander families who lived in the close-knit community. Well-known artists, Ian Fairweather and Donald Friend captured the essence of Malay Town, with its luxurious foliage, dark skinned people and simple wood and tin huts, in many of their paintings. Such was Fairweather's fondness for Malay Town; he preferred to refer to the area as a 'village' rather than a 'shanty' suburb of Cairns. Similarly, Donald Friend forged a life-long friendship with Charlie Sailor, known as the King of Malay town due to his wonderful baritone voice. Sailor, and his family, feature in many Donald Friend portraits.

Music and dance was at the heart of every day life in Malay Town. Therefore it is little wonder that a young Dulcie Pitt, the daughter of a Jamaican father and mixed heritage Aboriginal mother, became Australia's first indigenous Jazz singer. Pitt took the stage name of Georgia Lee and found fame at London's Royal Festival Hall. She went on to tour the world with Nat King Cole, before returning to Sydney as a cabaret singer. In her later years, Dulcie Pitt relocated to Cairns and, in 2010, died in her sleep aged 89 years.

Meanwhile Irukandji elder, George Skeene, who had published two papers on Aboriginal artifacts found in German museums, recalls a happy boyhood at the Lyons Street Aboriginal Reserve, which operated from the 1940s to 1959. (Skeene, Interview, 10 Sep. 2015)

"We didn't have much growing up, but we were happy. We swam in a freshwater swimming hole, now known as Goomboora Park, with some of the Djabugay group from Redlynch. It was a healthy marine environment with an abundance of bush tucker. We used to pick Blue Quandong, Burdekin Plums, River Cherry and Cocky Apples. I went to Balaclava State School and remember getting the cane for offering bush tucker to the other kids.

On weekends we liked going to the pictures at the Tropical, Plaza, Rex and Palace theatres. We were told to sit down the left-hand side of the theatre. Some of our white friends used to come over to sit with us. This was well before the 1967 referendum, but even then I knew segregation wasn't right."

Mixed marriages were also frowned upon. Aboriginal woman, Gladys O'Shane, who had married feisty Irishman, Patrick 'Tiger' O'Shane, became president of the Cairns and Torres Strait Islander Advancement League (CATSIAL), with Joe McGinness as secretary. The purpose of the League was to provide a voice for the indigenous community in their quest for equal rights. From an early age, Gladys O'Shane instilled in her children the fact they could do anything they set their minds to. Her eldest daughter Pat, who attended Cairns State High School, went on to 
become the first Aboriginal teacher in Queensland, the first female head of a State government department and the first Indigenous Australian to become a magistrate in the New South Wales courts.

As far as tourism is concerned, many celebrities such as Lee Marvin, Bob and Dolly Dyer, Ernest Borgnine and others put Cairns on the map of must-visit regions. In preparation for an influx of visitors Cairns GP, Dr Jack Barnes, began spending much of his time continuing the pioneering work of Dr Hugo Flecker into the dangers of marine stingers. Close friend and colleague, Dr Graham Cossins, recalls helping is friend was sometimes challenging. (Cossins, Interview, 1 Feb. 2016)

"Jack and I bought a second-hand, one cylinder, original Aqualung. He believed the only way to identify this almost invisible jellyfish was to take turns lying on the sea floor looking upwards to spot the tiny jellyfish, outlined by sunlight, swimming past. I never spotted a single one. But every weekend during the stinger season Jack, with the help of the Cairns and Ellis Beach lifesavers, kept going with the research. Sometimes Jack would deliberately sting himself to gauge the reaction, and I'd find myself chasing him around his house to inject him with Pethidine to relax his spasms. It was a fitting tribute when they named that tiny little jellyfish (Carukia barnesi) after him."

As well as identifying Carukia barnesi as the cause of Irukandji syndrome, Jack Barnes also identified the use of opioids as a useful treatment, proposed that other jellyfish may also cause 'pseudo-Irukandji' syndromes and instigated public health measures such as warning posters to educate the public. Jack Barnes, together with his assistant Ron Pollard and lifesavers in the region, tested the idea of using pantyhose as protection against jellyfish stings. This heralded the way for the later use of Stinger Suits.

Closer to town, as Hippies headed up the hill to Kuranda, artists began to take up residence at the northern beaches. Equestrian sculptor, Jennie Scott, recalls arriving as a Ten-pound-Pom in the mid-1960s and earning a few bob as a nude model for artists. (Scott, Interview, 1 July 2015)

"We'd have parties on the beach. Ron and Anne Edwards were great fun and I'd earn a bit of money posing for a number of the artists including Ray Crooke who told me I had perfect tits. Sometimes he'd colour them in."

Ray Crooke, who initially lived at Yorkeys Knob and relocated permanently to Cairns in his later life, recalls winning the 1969 Archibald prize. (Crooke, Interview, 12 January 2015).

"We were living in Sydney when Russell Drysdale encouraged me to become friendly with the writer George Johnston. He talked us into buying a house in the next street and my wife June became friendly with his wife. It was a difficult time for us all when she and their daughter committed suicide. A while later George asked if I would paint his portrait. At that time, I was an established landscape artist, but as I had had a very good teacher at Swinburne 
College in Melbourne, I obliged. I didn't set out to capture the troubled side of him, but that's what other people saw. One day the owner of a big art gallery in Sydney came by and saw the painting leaning against a wall and asked if he could enter it in the Archibald prize.

I recall it was school holiday time. We were on a boat ride somewhere in the Solomon Islands when the Australian news came on the wireless. The boat driver said, "Isn't that you?" I had to admit I was a bit surprised. I had other paintings that weren't even hung. I really didn't think the painting of George was anything special. I wouldn't have been put out if it hadn't won, but other people seemed to think I had captured the essence of George."

By the 1970, locals looked at ways to improve their skills at the new Technical And Further Education (TAFE) College that opened at Manunda. Young apprentices secured jobs as boilermakers and fitters and turners with North Queensland Engineers and Agents (NQEA), one of the largest employers in Cairns at that time. Others, including married women with children who had left school after grade 10, began to fulfil personal ambitions.

Government funding also became available for indigenous education with visual and ceramic artists such as Thancoupie encouraging Aboriginal and Torres Strait Islanders to fulfil their potential. Many Cairns indigenous artists, under the tutelage of Anna Eglitis at TAFE ATSI Visual Arts, have gained worldwide acclaim. (Eglitis, Interview, 11 Mar. 2016)

As far as opening up Cairns for business is concerned, the catalyst for change came in 1984 when the Cairns International Airport became a reality. High-rise buildings and five star hotels started springing up all over town to cater for the expanding tourism market, leaving some long-term residents fearing Cairns would soon become another Gold Coast.

Whilst the 1989 pilot's strike sent some businesses to the wall, by the mid1990s, when population reached 100,000, destination Cairns was on an upward trajectory. Entrepreneurial businessmen such as George Chapman looked at environmentally friendly ways to construct a cableway over the rainforest canopy between Smithfield and Kuranda. Happy to be called 'The boy from Mt Molloy', Chapman reflects on the influence of his father to educate him in the ways of the world. (Chapman, Interview, 9 July 2014)

"My fondest and most enduring memory is of penciling for my father at the races when I was a lad. Every section of society gathers at the races and I learned very quickly how to read and understand people."

After opening his first surveying practice in Cairns at the age of 23, George Chapman (AO) spent a lifetime in the service Cairns as one of our most highly respected business leaders. 
Next door to Skyrail, the opening of the Tjapukai Aboriginal Cultural Park saw a combined tourist experience develop as indigenous locals, keen to take control of their own destiny, began looking at unique ways to market their culture.

Meanwhile, in 1995, James Cook University's Cairns Campus became a reality. No longer did Professors and Lecturers such as Stephen Torre, Dawn May, Janice Wegner and others have to endure the cramped cupboard-like conditions at Cairns TAFE with the opening of the School of Arts and Social Sciences earmarked for A-Block. Unfortunately Associate Professor Henry Crowther, who died in 1990, did not see his dream of a local university in Cairns being realised. Nevertheless, his name lives on with the naming of the Crowther Lecture theatre, which honours the university's first Rector.

Since then the campus has seen exponential growth with Cairns students no longer needing to leave town to gain a first class education; whilst the university itself has become increasingly global in focus.

In conclusion, whilst this paper is just a snapshot of the proposed book, the work is designed to create new knowledge by capturing and sharing first-hand stories of people who have contributed to the growth of Cairns from small remote outpost to the desirable must-see cosmopolitan city we see today.

\section{Works Cited}

"Post-War Immigration: 1945-1998". Journal of the Australian Population Association. Vol 15 (2): 17.

Ian Fairweather to Jock Frater, July 1939, quoted in Bail, M., Fairweather, Murdoch Books, Sydney, revised edition 2009, p. 59.

Williamson, J. A., Fenner, P.J., Burnett, J W., Rifkin, J.F. Eds. Venomous and Poisonous Marine Animals: A Medical and Biological Handbook. Barnes J H. University of New South Wales Press. 1996. pp 115-129.

\section{Interviews by the Author}

Bianco, Frank. "Migrant” Interview with Carol Libke. Cairns. 4 Apr. 2015.

Chapman, George. "Entrepreneur.” Interview with Carol Libke. Cairns. 9 July 2014.

Cominos, Peter. "Businessman-Philanthropist." Interview with Carol Libke. Cairns. 8 Aug. 2015.

Cossins, Dr Graham. "Medical Practitioners." Interview with Carol Libke. Cairns. 1 Feb. 2016.

Crooke, Ray. “Artist.” Interview with Carol Libke. Cairns. 12 January 2015. 
Davis, Ron. "Mayor.” Interview with Carol Libke. Cairns. 12 Feb. 2015.

Eglitis, Anna. “TAFE.” Interview with Carol Libke. Cairns. 11 Mar. 2016.

Norman, Bob. "Sir Robert Norman and Bush Pilots." Interview with Carol Libke. Cairns. 26 Mar. 2015.

Scott, Jennie. "Musings of a Ten-Pound-Pom." Interview with Carol Libke. Cairns. 1 July 2015.

Skeene, George. “Indigenous Elder.” Interview with Carol Libke. Cairns. 10 Sep. 2015.

Wah Day, George. "Chinese Agriculture.” Interview with Carol Libke. Cairns. 5 Jun. 2015. 